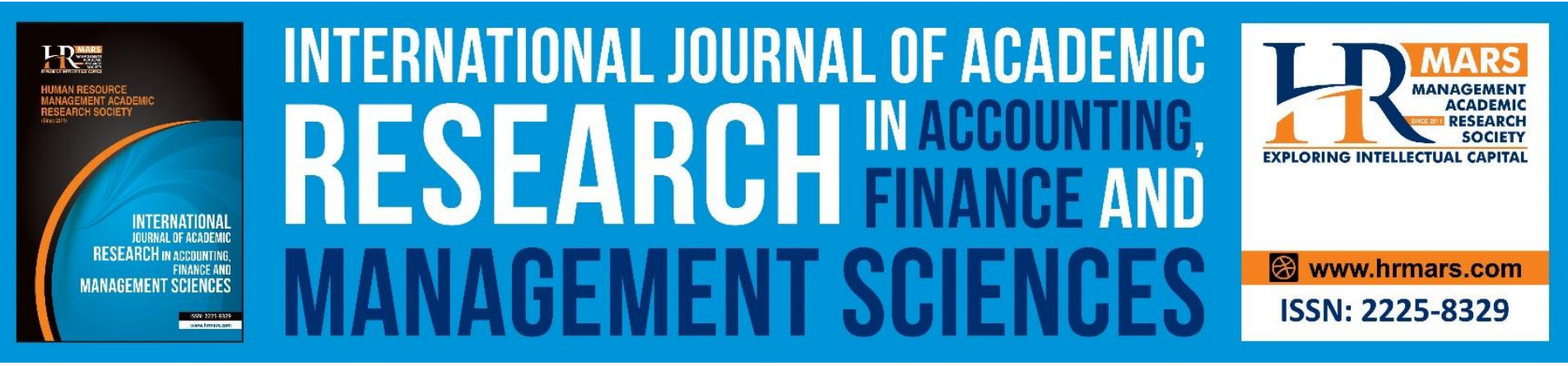

\title{
Characteristic of Board Directors and Financial Performance: Evidence from Companies Listed in Ftse Bursa Malaysia KIci Index
}

Mohamad Nizam Jaafar, Amirul Afif Muhamat, Wan Shahdila Shahar, Siti Zaitun Saddam

To Link this Article: http://dx.doi.org/10.6007/IJARAFMS/v11-i1/9091

DOI:10.6007/IJARAFMS /v11-i1/9091

Received: 20 January 2021, Revised: 21 February 2021, Accepted: 10 March 2021

Published Online: 28 March 2021

In-Text Citation: (Jaafar et al., 2021)

To Cite this Article: Jaafar, M. N., Muhamat, A. A., Shahar, W. S., \& Saddam, S. Z. (2021). Characteristic of Board Directors and Financial Performance: Evidence from Companies Listed in Ftse Bursa Malaysia Klci Index. International Journal of Academic Research in Accounting Finance and Management Sciences, 11(1), 512528.

\section{Copyright: (C) 2021 The Author(s)}

Published by Human Resource Management Academic Research Society (www.hrmars.com)

This article is published under the Creative Commons Attribution (CC BY 4.0) license. Anyone may reproduce, distribute, translate and create derivative works of this article (for both commercial and non-commercial purposes), subject to full attribution to the original publication and authors. The full terms of this license may be seen

at: http://creativecommons.org/licences/by/4.0/legalcode

\section{Vol. 11, No. 1, 2021, Pg. 512 - 528}

Full Terms \& Conditions of access and use can be found at http://hrmars.com/index.php/pages/detail/publication-ethics 


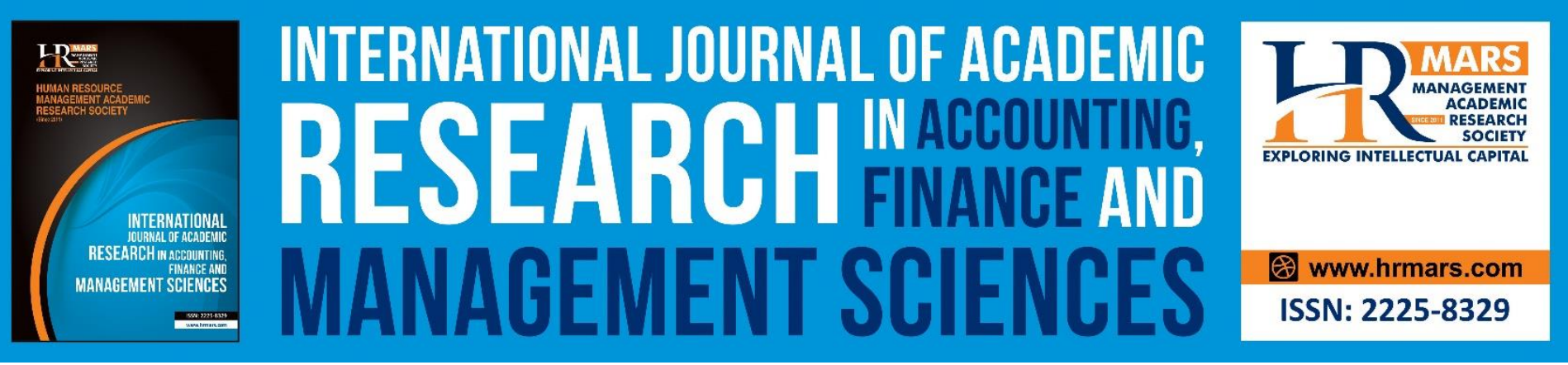

\title{
Characteristic of Board Directors and Financial Performance: Evidence from Companies Listed in Ftse Bursa Malaysia KIci Index
}

\author{
Mohamad Nizam Jaafar \\ Senior Lecturer, Arshad Ayub Graduate Business School, Universiti Teknologi MARA, Shah Alam, \\ Selangor, MALAYSIA
}

Amirul Afif Muhamat

Senior Lecturer, Faculty of Business Management, Universiti Teknologi MARA, Puncak Alam, Selangor, MALAYSIA

Wan Shahdila Shahar
Lecturer, International Islamic University College Selangor, MALAYSIA

Siti Zaitun Saddam

Senior Lecturer, Faculty of Business Management, Universiti Teknologi MARA, Puncak Alam, Selangor, MALAYSIA

\begin{abstract}
Corporate governance is an effective mechanism to supervise and evaluate decisions made by a firm. It also could curtail the agency cost and information asymmetry between the management and stakeholders. The role of corporate governance thru the presence of board of directors has received increased attention across a number of disciplines in recent years. Thus, this study intended to examine the relationship between board characteristics and firms' performance. Panel data regression of Fixed Effect Model was applied to estimate the influence of the board characteristics and performance (ROA) of firms listed in the FTSE Bursa Malaysia KLCI Index starting from 2011 to 2019. The findings have indicated that board size, board meeting and director's higher educational qualification are the characteristics that significantly influenced firm's performance. However, in oppose to the expectations of the study, inconclusive results are found concerning board independence. The result also shows that composition of board gender does not influence firms' performance, although several initiatives have been made to reform corporate governance. This result managed to ascertain the board directors' characters that influence the firms' performance
\end{abstract}


INTERNATIONAL JOURNAL OF ACADEMIC RESEARCH IN ACCOUNTING, FINANCE AND

MANAGEMENT SCIENCES

Vol. 11, No. 1, 2021, E-ISSN: 2225-8329 @ 2021 HRMARS

and provided a useful insight to policy makers for their supervision purposes. As such, this paper offers several implications for corporate governance and firm performance.

Keywords: Behavioural Finance, Corporate Governance, Board of Director, Fixed Effect Model, FTSE Bursa Malaysia Index.

\section{Introduction}

Observing the current challenges in business settings, the role as the board directors is tremendously challenging as it is to safeguard the interest and maintain sustainability of the firm. The board of directors' tasks are not limited to monitoring the performance of the firm, but they also need to offer strategic guidance and provide support if the firm is having any financial difficulties. The board of directors must ensure that every firm acts on any chances that can enhance the value to all stakeholders, and to avoid negative management practices that may expose it to corporate failure and scandals. There are several evidences of failures that can be observed on some big corporations around the globe and corporate scandals such as Parmalat Inc, Enron Inc, Ahold Inc, Adelphia Inc, Worldcom Inc, Felda Berhad, 1MDB and many more. The failures of the above mentioned firms were due to the ineffectiveness of the role of the board of directors.

Board composition is a part of corporate governance which focuses on the interaction among directors, shareholders, and corporate managers where it is designed to minimize any potential problem that arises in the interest management among shareholders. Besides that, corporate governance affects the way on how the firm is being controlled, directed, and administered. According to Shah, Butt and Saeed, (2011), they found that corporate governance influences the management of the firm being by the way of the general public, customers, governments, employees, creditors, managers, and shareholders. On the other hand, corporate governance is the mechanism that protects shareholder's interests (Shahid \& Abbas, 2019) as there is a possibility of abuse of power by management of the firm when organizational governance structures are weak (Core, Holthausen, \& Larcker, 1999). Corporate governance will give the assurances to shareholders that managers will run the companies accordingly which eventually will increase the value of the firm. Based on the study of Denis, and McConnell (2003), they found that an effective corporate governance and utilizing resources of a firm have a positive relationship with the firms' performance and improve shareholders' confidence toward the firm. Last but not least, corporate governance via effective function of their board can prevent the firms from any expropriation of the funds by the manager and help the management on making a better decision making.

In Malaysia, to establish corporate governance practice, the Malaysian Code on Corporate Governance (MCCG) was first issued in 2000 and later reviewed in 2007 and 2012 to ensure that it continued to be significant and is in line with internationally accepted best practices and standards. Eventually in 2017, the MCCG, which replaced its previous edition, took on a new method to encourage better internalisation of corporate governance culture.

Due to the importance of corporate governance especially identifying the effective characteristic of the board director, there are numerous studies conducted on the relationship between the role of the board and the firm's performance. For example, (Prabowo, 2010; Rashid, Zoysa, Lodh, \& Rudkin, 2010; Adika, Maru, \& Mugambi, 2018; García Martín \& Herrero 2018; Al-Swidi, Fadzil, \& Al-Matari, 
INTERNATIONAL JOURNAL OF ACADEMIC RESEARCH IN ACCOUNTING, FINANCE AND MANAGEMENT SCIENCES

Vol. 11, No. 1, 2021, E-ISSN: 2225-8329 @ 2021 HRMARS

2012; Kaur, \& Vu, 2017) have discussed every aspect from composition, characteristics and the effect on firm performance. Certain factors such as transparency, independence of the board, the board diversity and active participation of strategic decision making have been observed to improve the effectiveness of the board. Nevertheless, the final findings are still unfounded. There is still no final outcome among the researchers that find specific variables that can explain the performance of firms' relationship with board characteristics. For example, Dalton, Daily, Ellstrand and Johnson (1998), Laing and Weir (1999); Weir, Laing \& McKnight (2002) find no evidence to suggest that board characteristics affect firm performance. However, other studies have established a positive effect between certain characteristics of board and firm's performance (Bhagat \& Black, 2002; Kiel \& Nicholson, 2003; Bonn et al., 2004). There are several studies in the area of corporate governance, revealing that a negative relationship between board characteristics and board composition on firm performance (ROA) in Malaysia listed companies and Saudi Arabia (Jakpar et al., 2019; Ghabayen, 2012). Meanwhile, there is a positive relationship between the board size and CEO duality on firm performance in Romania and Kuwaiti (Moscu, 2013).

Due to inconclusive previous findings, this study attempted to provide an insight into how board characteristics influenced the firm performance. Besides, this study focusses on firms listed on FTSE Bursa Malaysia Index Series as it encompasses the largest companies by a full market capitalization that consists of 30 constituents in the index. The index represents the shares listed on Bursa Malaysia Main Market which represents the performance of the largest Malaysia blue-chip companies that are accepted by their size, free float, and liquidity screens. As such, it is considered as the best company listed on Bursa Malaysia and a good proxy for the whole companies listed on Bursa Malaysia. Therefore, the outcomes of this study is expected to bring new approaches for researchers and regulators on the importance of board of director's characteristics and firm performance.

\section{Literature Review and Hypothesis Development}

A conflict between managers and shareholders is suggested to be mitigated through the effective internal corporate governance with the presence BOD. The literatures suggest that board of director is a body to monitor, discipline and advice the top management (Chow, Muhammad, Bany-Ariffin, \& Cheng, 2018; participate in strategic decision process (Kamardin \& Haron, 2011); became resource dependence roles (Ntim, 2015); have the authority to appoint, dismiss, evaluate and compensate the management team including CEOs (Baysinger \& Butler, 1985); and monitor the firm's performance (Kamardin \& Haron, 2011). These duties are closely related to the fundamental roles of BOD in mitigating the agency cost that arise between managers and shareholders; and therefore, would increase the firm's performance and protect the shareholders' wealth. For that reason, most of the past evidences show that board of director have significant influence on strategic decision-making (Heng et al., 2012; Tarus \& Ayabei, 2016; and Hasan \& Butt, 2009) and positively related to firm's performance (Gurusamy, 2017; and Erhardt, Werbel, \& Shrader, 2003). Besides, previous studies found that board diversity is one of the main and important elements for internal governance characteristics (Nuhu \& Ahmad, 2017), and plays an essential function in monitoring the firms' manager (Bear, Rahman \& Post, 2010). In the governance literature, there are several variables used in measuring board characters for example board size, frequency of annual board meetings, gender board diversity, board independence, board education, etc. 
INTERNATIONAL JOURNAL OF ACADEMIC RESEARCH IN ACCOUNTING, FINANCE AND

MANAGEMENT SCIENCES

Vol. 11, No. 1, 2021, E-ISSN: 2225-8329 @ 2021 HRMARS

Board size refers to the number of members on the board of directors (Isik \& Ince, 2016). There are other findings that show a positive relationship between board size and firm performance by used theory agency theory and resource dependency theory (Kalsie, \& Shrivastav, 2016; Agyemang Badu, \& Appiah, 2017; Kapil, \& Mishra, 2018). However, study by Hidayat and Utama (2017) using the sample data from the Indonesian Stock Exchange found that the relationship between board size and firm performance is found to have a negative result. Similarly, the result obtained from a study by Shukeri, Shin and Shaari (2012), shows that 300 Malaysian companies are listed publicly, they used an ROE and ROA as proxies and the relationship between board size and firm performance is found to be negative.

Though the result is inconclusive, it is assumed that larger boards sizw provide more expertise, greater management oversight and access to a wider range of resources. Therefore, the research hypothesis is established as follows:

\section{Hypothesis 1: Board size positively affects the firm performance}

The frequency of annual board meetings is measured to estimate the impact on firm performance. According to Lipton et al. (1992) and Jensen (1993), the frequency of board meetings can be considered to evaluate the supervising authority and effectiveness of the board of directors. If the board meetings are held often throughout the year, the better the firm performs. There are various studies of the frequency board meeting and firm performance, such as the study implemented by Aryani et al. (2017), the result shows the number of board meetings does not affect the firm performance - Return on Assets (ROA) as proxy. The sample data is from several companies registered in the Jakarta Islamic Index from 2006 to 2016. This is contrasting to the research by Ting, Kiong, Kweh, and Hoanh, (2018), which found that the frequency of board meetings exerts a negative effect on the financial performance of the firms. Sample data consisted of 94 firms listed on the Ho Chi Minh Stock Exchange from 2013 to 2015. Contrary to the result of the study by Buchdadi et al. (2019), the findings reveal that board meeting, and the board meeting attendance has a positive impact on market value and accounting-based performance respectively.

\section{Hypothesis 2: High number of board meeting positively affects the firm performance}

Gender diversity encompasses an unbiased board of directors that represent fair numbers of men and women. Chen, Leung, Song, and Goergen (2019), Terjesen et al. (2016) and Bear et al. (2010) found gender diversified of board significantly leads to better corporate decisions. Given that note, Marinova et al. (2010), suggested that improvement of firm performance is an attribute to the higher number of women on the board and top executive positions. The participation of women on the board is expected to help firms to enhance performance and increase competitive advantages. Female directors on the board are expected to offer a further cooperative style to leadership, which improves effective communication management on the board (Konrad \& Kramer, 2006). According to Burke (2003), further advantage of having women on board will lessen the possibility of further corporate board crisis therefore improves an efficient performance by the board. Besides, according to Carter et al. (2003), there is a positive relationship between the percentage of women on the board of directors and firm value. Nonetheless, according to Rose (2007), there is an insignificant 
INTERNATIONAL JOURNAL OF ACADEMIC RESEARCH IN ACCOUNTING, FINANCE AND

MANAGEMENT SCIENCES

Vol. 11, No. 1, 2021, E-ISSN: 2225-8329 @ 2021 HRMARS

relationship between female board representation and firm performance in Denmark. According to the resource dependency theory, if women can reach the highest of their capabilities, they can definitely conduct the company successfully based on their skills, ingenuity, and flexibility (Salancik \& Pfeffer, 1978; Krishnan \& Park, 2005).

\section{Hypothesis 3: More female directors positively affects the firm performance}

Board independence are the outside non-executive (Terjesen et al., 2016; and Alkdai and Hanefah, 2012), which do not have a material interest in the firms (Hooy \& Ali, 2017). Board independence can be measured by using the fraction of independent non-executive directors to the total number of directors (Prabowo \& Simpson, 2011; Abdullah \& Nasir 2004). Bursa Malaysia defined independent directors as a director who is free from business or other relationships which could influence the independent judgment. According to Makhlouf, et al. (2017), they examined the board's independence as one of the factors towards firm performance based on a final sample of 120 firms (Industry and services sectors) listed on the Amman Stock Exchange over a period from 2009 to 2013. Their result found that the relationship between board independence and firm performance was positive by using Tobin's $Q$ and ROA as proxies.

\section{Hypothesis 4: Board independent positively affects the firm performance}

According to Gottesman and Morey (2006), levels of education represent intelligence, as the educated managers are expected to perform better than their peers. Nevertheless, managerial skills or not solely based on educational level.

The findings of the paper from Nigeria by Okon, (2014), Endraswati, (2018), Saidu, (2019), they find out that the relationship between the board of directors, women and CEO with education and the firm performance was positive. The ROA, ROE and stock price as a proxy have measured that CEO with education gives an impact on firm performance positively by applying agency theory.

Hypothesis 5: Higher Board Director education positively affects the firm performance 
INTERNATIONAL JOURNAL OF ACADEMIC RESEARCH IN ACCOUNTING, FINANCE AND MANAGEMENT SCIENCES

Vol. 11, No. 1, 2021, E-ISSN: 2225-8329 @ 2021 HRMARS

Table 1: Explains the proxies used for dependent variables and independent variables.

\begin{tabular}{|c|c|c|}
\hline Variables & Measurement & Author \\
\hline \multicolumn{3}{|l|}{ Dependent Variables } \\
\hline $\begin{array}{l}\text { Firm Performance } \\
\text { (ROA) }\end{array}$ & ROA $=\frac{\text { Net income }}{\text { Total assets }}$ & $\begin{array}{l}\text { Jakpar et al., 2019) and } \\
\text { (Ghabayen, 2012) }\end{array}$ \\
\hline \multicolumn{3}{|l|}{ Independent Variables } \\
\hline Board Size (BSIZE) & $\begin{array}{l}\text { Total number of } \\
\text { board members }\end{array}$ & $\begin{array}{l}\text { Hidayat and Utama (2017); } \\
\text { Shukeri, Shin and Shaari (2012) }\end{array}$ \\
\hline Board Meeting (BMEET) & $\begin{array}{l}\text { Number of board meetings } \\
\text { annually }\end{array}$ & Aryani et al. (2017) \\
\hline $\begin{array}{l}\text { Gender of boards } \\
\text { members } \\
\text { (GEND) }\end{array}$ & $\frac{\text { Number of female directors }}{\text { Total of board members }} \times 100$ & $\begin{array}{c}\text { Shahdila-Shahar, Ahmad, and } \\
\text { Jaafar, N (2019) }\end{array}$ \\
\hline $\begin{array}{l}\text { Independence of board } \\
\text { (INDE) }\end{array}$ & $\frac{\text { Number of outside directors }}{\text { Total of board members }} \times 100$ & $\begin{array}{l}\text { Makhlouf, et al. (2017), Azar, } \\
\text { Rad, and Botyari (2014) }\end{array}$ \\
\hline $\begin{array}{l}\text { Board Education } \\
\text { (EDU) }\end{array}$ & $\begin{array}{l}\text { Number of directors with } \\
\frac{\text { Master and } \mathrm{PhD}}{\text { Total of board members }} \times 100\end{array}$ & $\begin{array}{l}\text { Endraswati, (2018), Saidu, (2019); } \\
\text { Shahdila- Sahar, Ahmad, N and } \\
\text { Jaafar, N (2020) }\end{array}$ \\
\hline \multicolumn{3}{|l|}{ Control Variables } \\
\hline Firm size & Natural logarithm of total assets & $\begin{array}{c}\text { Jaafar, N, Muhamat, A, Ismail and } \\
\text { Sharifah (2017). }\end{array}$ \\
\hline Leverage & $\frac{\text { Total debt }}{\text { Total Asset }}$ & $\begin{array}{c}\text { Jaafar, N, Muhamat, A, Hairul } \\
\text { Nizam, Ahmad, I and Syed Alwi, S } \\
\text { (2017) }\end{array}$ \\
\hline Growth & $\frac{\text { Current year sales - prev. year sales }}{\text { Previous year sales }}$ & Babu and Chalam (2014). \\
\hline
\end{tabular}

\section{Methodology}

\section{a. Sample}

We conducted descriptive and analytical research designs. The study used secondary data collection and the data was retrieved from annual report of 30 companies listed on the FTSE Bursa Malaysia $\mathrm{KLCl}$ Index from year 2011 to 2019 . The study has analysed 270 observations $(n=270) \mathrm{d}$.

\section{b. Model Specification}

This study use fixed-effects panel regression analysis because sample contained data across firms and over time. Besides, panel data sets are better to identify and estimate effects that clearly are not 
INTERNATIONAL JOURNAL OF ACADEMIC RESEARCH IN ACCOUNTING, FINANCE AND

MANAGEMENT SCIENCES

Vol. 11, No. 1, 2021, E-ISSN: 2225-8329 @ 2021 HRMARS

investigable in pure time series or cross-sections data. Fixed effects regressions control for, or partial out, the effects of time-invariant variables with time-invariant effects. When firm heterogeneity is unobservable, a fixed effects specification helps capture the effect of the unobservable variable (Chi, 2005) otherwise random effect regression should be employed.

As such, to determine the effect of board characteristic on firm performance, the following baseline regression is established Equation (1).

$$
\begin{gathered}
\mathrm{ROA}_{i t}=\alpha_{0}+\beta_{1} \mathrm{BSIZE}_{i t}+\beta_{2} \mathrm{BMEET}_{i t}+\beta_{3} \mathrm{GEND}_{i t}+\beta_{4} \mathrm{INDE}_{i t}+\beta_{5} \mathrm{EDU}_{i t}+\beta_{6} \mathrm{FSize}_{+} \\
\beta \mathrm{LEV}+\beta_{8} \mathrm{Growth}^{-\varepsilon_{i t}}
\end{gathered}
$$

Where,

$$
\begin{aligned}
& \text { ROA }_{i t}=\text { Firm Performance (ROA) } \\
& \alpha_{0}=\text { Constant } \\
& \text { BSIZE }_{i t}=\text { Board Size of company } i \text { at year } t \\
& \text { BMEET }_{i t}=\text { Board Meeting of company } i \text { at year } t \\
& \text { GEND }_{i t}=\text { Gender of boards members of company } i \text { at year } t \\
& \text { INDE }_{i t}=\text { Independence of board of company } i \text { at year } t \\
& \text { EDU }_{i t}=\text { Board Education of company } i \text { at year } t \\
& \text { FSize }_{i t}=\text { Firm Size } i \text { at year } t \text { (control variable) } \\
& \text { Firm Leverage } \\
& \text { Firm } \text { Firm Laverage } i \text { at year } t \text { (Control Variable) } \\
& \varepsilon_{i t}=\text { Error }_{i t} \text { Firm growth } i \text { at year } t \text { (control Variable) } \\
& \beta_{1}, \beta_{2}, \beta_{3}, \beta_{4} \text { and } \beta_{5}=\text { Regression coefficients }
\end{aligned}
$$

The label ROAit shows the dependent variable in this study and represents firm performance which is used for profitability (return on asset) for firm i in year t. Meanwhile, the other independent variables are BSIZEit, board size which shows the relationship between numbers of boards over the firm performance. BMEETit, board meeting is measured by the frequency of board meetings annually and its relation to the return on assets. GENDit, gender of boards' members expresses the relationship between proportions of female on boardroom with the profitability of firm. INDEit as the independence of board shows the ratio of board independent in board and its relation to return on assets of firms. EDUit is the indicator of the percentage of directors with a higher educational qualification and its relation to the firm performance. Meanwhile, Firms' size, Firm's Leverage and Firms' Growth are our control variable. Lastly, it labels are represented as cross-sectional and time series in this panel data study.

\section{Results and Discussion}

Table 2 presents a summary of statistics for variables used in the analysis. Total observations in this study were 30 companies listed on the FTSE KLCI INDEX Market of Bursa Malaysia stock exchange. Firm performance as measured by return on assets is represented by a 7.6\% return on each dollar on assets invested. The average firm in FTSE Index market is 23 which is considered as big size and classified as a blue chip counter. Meanwhile, grow opportunity is an average of $7.4 \%$ with the standard deviation is 0.32 . Average Board Size for the companies listed under FTSE KLCI Index is 9 
INTERNATIONAL JOURNAL OF ACADEMIC RESEARCH IN ACCOUNTING, FINANCE AND MANAGEMENT SCIENCES

Vol. 11, No. 1, 2021, E-ISSN: 2225-8329 @ 2021 HRMARS

members with 8 times meetings per annum. $17 \%$ of the board members consist of female directors and $33 \%$ directors are highly qualified.

Table 2: Descriptive Analysis

\begin{tabular}{|c|c|c|c|c|c|c|c|c|}
\hline & ROA & BSIZE & BMET & INDE & EDU & FSIZE & LEV & GRO \\
\hline \multirow[b]{2}{*}{ Mean } & 0.076 & 9.185 & & & 0.3358 & 23.86 & 0.527 & 0.07400 \\
\hline & 21 & 18 & 8. & 0.64 & 15 & 03 & 643 & 8 \\
\hline \multirow[b]{2}{*}{ Median } & 0.052 & 9.000 & & & 0.3100 & 23.83 & 0.495 & 0.05638 \\
\hline & 50 & 00 & 7. & 0.57 & 00 & 59 & 000 & 2 \\
\hline \multirow{2}{*}{$\begin{array}{c}\text { Maximu } \\
\mathbf{m} \\
\end{array}$} & 0.472 & 15.00 & & & 0.8600 & 27.44 & 0.950 & 2.21130 \\
\hline & 00 & 00 & 25. & 1.0 & 00 & 59 & 000 & 9 \\
\hline \multirow{3}{*}{$\begin{array}{c}\text { Minimu } \\
\mathbf{m}\end{array}$} & - & & & & & & & - \\
\hline & 0.082 & 5.000 & & & 0.0000 & 17.53 & 0.041 & 2.85700 \\
\hline & 00 & 00 & 4. & 0.14 & 00 & 66 & 700 & 0 \\
\hline \multirow[b]{2}{*}{ Std. Dev. } & 0.079 & 1.993 & & & 0.1880 & 1.979 & 0.278 & 0.32804 \\
\hline & 07 & 22 & 4.52 & 0.19 & 19 & 60 & 268 & 7 \\
\hline \multirow{3}{*}{$\begin{array}{c}\text { Skewnes } \\
\text { s }\end{array}$} & & & & & & - & & - \\
\hline & 1.871 & 0.632 & & & 0.4032 & 0.735 & 0.066 & 1.27859 \\
\hline & 70 & 35 & 1.22 & 0.37 & 71 & 268 & 379 & 7 \\
\hline \multirow[b]{2}{*}{ Kurtosis } & 7.611 & 2.727 & & 2.19 & 2.9427 & 4.147 & 1.754 & 39.2580 \\
\hline & 88 & 3 & 3.72 & - & 47 & 78 & 494 & 0 \\
\hline \multirow{2}{*}{$\begin{array}{c}\text { Jarque- } \\
\text { Bera }\end{array}$} & 396.9 & 18.82 & 73.55 & 13.5 & 7.3551 & 39.14 & 17.65 & 14863.3 \\
\hline & 24 & 37 & 63 & 63 & 6 & 86 & 024 & 0 \\
\hline \multirow{2}{*}{$\begin{array}{c}\text { Probabili } \\
\text { ty }\end{array}$} & 0.000 & 0.000 & 0.000 & 0.00 & 0.0252 & 0.000 & 0.000 & 0.00000 \\
\hline & 0 & 08 & 00 & 12 & 5 & 00 & 147 & 0 \\
\hline \multirow[b]{2}{*}{ Sum } & 20.59 & 2480. & 2314. & 171. & 90.670 & 6444. & 142.4 & 19.9820 \\
\hline & 09 & 00 & 0 & 79 & 06 & 63 & 635 & 9 \\
\hline \multirow{2}{*}{$\begin{array}{l}\text { Sum Sq. } \\
\text { Dev. }\end{array}$} & 1.681 & 1068. & 5566. & 9.50 & 9.5094 & 1051. & 20.82 & 28.9483 \\
\hline & 95 & 71 & 16 & 47 & 33 & 35 & 953 & 4 \\
\hline \multirow{2}{*}{$\begin{array}{c}\text { Observat } \\
\text { ions }\end{array}$} & & & & & & & & \\
\hline & 270 & 270 & 270 & 270 & 270 & 270 & 270 & 270 \\
\hline
\end{tabular}

\section{Diagnosis Test}

Pearson Correlation Matrix is used to detect multicollinearity. According to Astreiou and Hall (2015), the large number of researchers which consider value of 0.9 is the threshold. If the correlation between sampled variables is more than 0.9 , then it shows the multicollinearity problem exists in the sample data. In this study, the highest correlation was between ROA and EDU which was at 0.114939 and significance at $\alpha=0.10$. Thus, it can be concluded that there was no multicollinearity issue in the sample data for 30 companies listed in the FTSE Bursa Malaysia KLCI Index. Please refer to table 3 in the appendix for the Pearson Correlation Matrix. 
INTERNATIONAL JOURNAL OF ACADEMIC RESEARCH IN ACCOUNTING, FINANCE AND

MANAGEMENT SCIENCES

Vol. 11, No. 1, 2021, E-ISSN: 2225-8329 @ 2021 HRMARS

\section{Likelihood Ratio Test}

Likelihood Ratio Test is applied in this study to choose the best model between Pooled Ordinary Least Squares (POLS) model and Fixed Effects Model (REM). The hypotheses under Likelihood Ratio Test are as follows:

$\mathrm{HO}=$ POLS model is preferred

$\mathrm{H} 1$ = Fixed Effects Model is preferred

Table 4: Likehood Ratio Test

\begin{tabular}{|c|c|}
\hline Effects Test & Statistics (P-Value) \\
\hline Cross-section F & 23.625466 \\
& $(0.0000)^{* * *}$ \\
\hline Cross-section Chi-square & 371.995974 \\
& $(0.0000)^{* * *}$ \\
\hline
\end{tabular}

P-value of cross-section F and cross-section Chi-Square statistics were 0.0000 . Therefore, it is statistically significant as the $p$-value is less than $\alpha=0.01$. The null hypothesis in Likelihood Ratio Test is rejected and the Fixed Effects Model (FEM) is chosen.

\section{Hausman Test}

The Hausman specification test was conducted to compare fixed effects and random effects estimations in selecting the most appropriate model estimation (Baltagi, Bresson and Pirotte, 2003; Hsiao, 2007). As the random effects model assumes the exogeneity of all of the regressors and the random individual effects, the fixed effects model allows for endogeneity of all of the regressors, as well as individual effects (Mundalk, 1978). Therefore, Hausman and Taylor (1981) introduced a model in which some of the regressors are correlated with individual effects. This indicates that the individual means of the strictly exogenous regressors are used as instruments for the time invariant regressors, which are correlated with the individual effects. Therefore, the choice of exogenous regressors is a testable hypothesis.

The hypotheses statement are as follows:

$\mathrm{HO}=$ Random Effects model is preferred

$\mathrm{H} 1$ = Fixed Effects model is preferred

Based on Table 5 above shows $p$-value of cross-section random statistic for 30 companies listed on the FTSE Bursa Malaysia KLCI Index was 0.0010. Since the $p$-value less than $\alpha=0.10$, the statistics are significant. This means that the null hypothesis was rejected and it can be concluded that Fixed Effect Model was preferred. 
INTERNATIONAL JOURNAL OF ACADEMIC RESEARCH IN ACCOUNTING, FINANCE AND MANAGEMENT SCIENCES

Vol. 11, No. 1, 2021, E-ISSN: 2225-8329 ๔ 2021 HRMARS

Table 5: Hausman Test

\begin{tabular}{|c|c|}
\hline Test Summary & Statistics (P-Value) \\
\hline Cross-section random & 26.219461 \\
& $(0.0001)^{* * *}$ \\
\hline
\end{tabular}

Note: $* * *$ denotes significant at $1 \%$

For 30 companies listed on the FTSE Bursa Malaysia KLCI Index for the period of 2011 to 2019, the pvalues of board size (BSIZE), board meeting (BMEET) and board education (EDU) were 0.0000, 0.0002 and 0.0054 respectively. The $p$-values were less than $\alpha=0.01$ which means these variables were statistically significant at $1 \%$ level of significance. However, gender of board (GEND) and independence of board (INDE) were having results of $p$-values that have insignificant effect for firms' ROA that constituted more than $10 \%$ level of significance which are 0.2098 and 0.6767 .

This study showed that the negative coefficient for BSIZE and BMEET constituted that $1 \%$ change in BSIZE and BMEET could negatively impact about 0.009910 and 0.003895 of the firms' ROA. However, GEND and INDE should be considered as having no significant impact on 30 companies listed on the FTSE Bursa Malaysia KLCI Index for the period of 2011 to 2019. The number of female directors and non-executive directors in a boardroom does not affect the profitability of companies listed on the FTSE Bursa Malaysia KLCI Index. Whereas, EDU has a positive significant impact towards ROA. Thus, more directors with master and $\mathrm{PhD}$ holders on board, more gained profit by companies listed on the FTSE Bursa Malaysia KLCl Index.

Model Fit Test was conducted in order to see whether the Fixed Effects model could fit the data well in this study. The F-statistic contributed to 21.72051 with $0.000000 \mathrm{p}$-values. The $p$-value was less than $\alpha=0.01$ which indicates that the Fixed Effect model is significant at $1 \%$ and fits the sample data well. Additionally, the adjusted R-squared value was 0.381274 , which indicates that $38 \%$ return of assets of the 30 companies listed on the FTSE Bursa Malaysia KLCI Index can be explained by the selected independent variables.

Based on the regression results obtained, that the board education (EDU) which was represented by the board characteristics of the company was a statistically significant determinant of return on asset (ROA) of the 30 companies listed on the FTSE Bursa Malaysia KLCI Index for the period of 2011 to 2019. It can be concluded that EDU portrays the most influential variable that affects the performance of the companies listed on the FTSE Bursa Malaysia KLCI Index in terms of profitability as it has the highest coefficient as compared to other variables. Empirical result on directors higher educational qualification (Master degree and $\mathrm{PhD}$ ), their presence was significantly and positively related with firm performance. This indicates that educational qualifications equip directors with knowledge, better managerial and administrative skills in the managing of the company's affairs. Also, directors with Master and PhD holders in the company are vital and paramount in determining the firms' performance. Previous research by Amran (2010) and Ujunwa (2012) proved that directors with degree qualification significantly affect firm performance.

For Board Size (BSIZE) and Board Meeting (BMEET), it was found that they are statistically significant at $1 \%$ significance level which gave a negative impact to firms' ROA. For BSIZE, the findings showed 
INTERNATIONAL JOURNAL OF ACADEMIC RESEARCH IN ACCOUNTING, FINANCE AND MANAGEMENT SCIENCES

Vol. 11, No. 1, 2021, E-ISSN: 2225-8329 @ 2021 HRMARS

that the larger number of members in the boardroom will negatively affect the profitability of firms (ROA). This implies that the large board size tends to ineffectiveness on performance of firms. For BMEET, the results explained that the more meetings held annually, it will negatively affect the firms' performance (ROA). This indicates that higher frequency board meetings held annually, the lower profit acquired. This happens may because of the low quality of the meeting and the regular meeting held does not give a positive impact on the profitability of companies.

Besides, for both of the gender diversity (GEND) and Board Independence (INDE) were found to be statistically insignificant and did not give any influence towards firm performance of the 30 companies listed on the FTSE Bursa Malaysia KLCI Index. For GEND, the results show that the numbers of females in the boardroom was not a vital aspect to drive the ROA of the companies. Moreover, the percentages of board independent in boardroom (INDE) is also to be found as not an important factor in determining the profitability of the 30 companies listed on the FTSE Bursa Malaysia KLCI Index.

The results of female on board (GEND) and board independence (INDE) were similar to studies done by Yasser (2012), Julizaerma \& Sori (2012) and Prabowo \& Simpson (2011). Based on previous studies, the results proved that the presence of females on board is not a contribution towards good governance. In addition, Wang \& Clift (2009) explained based on their result that there is no strong correlation between gender diversity on the board and financial performance. Contrasting to this, Kramer, et. al. (2008) elaborate that decision making can be better and fulfill the interest of the stakeholders when having more number of women in the boardroom. Also, the consistent results with Liu et al. (2014), Bianco et al. (2015) and Terjesen et al. (2016), suggest that female and nonexecutive directors in the boardroom do not necessarily contribute to a better firm performance. Based on the perspective of agency theory, independent directors may lack skills in supervising management because they lack insider information about the operating activities of their firms.

Additionally, the relationship board size (BSIZE) and board meeting (BMEET) are negative but there is a significant association with the firm performance. For the board meeting, the result shows negative correlation but the $p$-value is significant with the firm performance. This result may be due to the condition that frequent organised meetings resulted in high energy costs, travel expenses and expenses incurred for such meetings. Therefore, firms suffer because these costs negatively influence performance. Based on Bublykova, (2014) which revealed the similar result that the size Supervisory Board gives a negative impact on firm performance. Thus, the larger board size has more adverse impact on financial performance (ROA) as well as the huge board size are greatly inefficient because it leads to overweight benefits (Bublykova, 2014). Meanwhile, for the board education (directors who hold a master and $\mathrm{PhD}$ ) has a positive and significant impact on financial performance. The study has established that the directors are majority in higher level education hence they are broader in functional and educational background with a specialist's knowledge and have experiences to create a better chance of improving performance of firms (Kokeno \& Muturi, 2016). 
INTERNATIONAL JOURNAL OF ACADEMIC RESEARCH IN ACCOUNTING, FINANCE AND MANAGEMENT SCIENCES

Vol. 11, No. 1, 2021, E-ISSN: 2225-8329 ๔ 2021 HRMARS

Table 6: Fixed Effect Regression analysis

\begin{tabular}{cccc}
\hline Variables & Coefficient & t-statistics & (P-Value) \\
\hline BSIZE & -0.009910 & -4.616147 & $(0.0000)^{* * *}$ \\
BMEET & -0.003895 & -3.829457 & $(0.0002)^{* * *}$ \\
GEND & 0.037765 & 1.257175 & $(0.2098)$ \\
INDE & 0.010300 & 0.417406 & $(0.6767)$ \\
EDU & 0.070523 & 2.807703 & $(0.0054)^{* * *}$ \\
FIRMSIZE & -0.018124 & -8.136455 & $(0.0000)^{* * *}$ \\
LEVERAGE & 0.038221 & 2.194274 & $(0.0291)^{* *}$ \\
GROWTH & 0.002193 & 0.187724 & $(0.8512)$ \\
C & 0.575998 & 10.88545 & $(0.0000)^{* * *}$ \\
& & & \\
F-Statistics & & 21.72051 & \\
Adjusted R-Squared & & $0.000000)^{* * *}$ & \\
Durbin Watson & & 0.381274 & \\
\hline
\end{tabular}

Note: $* *, *$ denotes significance at $5 \%, 10 \%$ respective

\section{Conclusion}

We have investigated the relationship between board characteristics and firm performance. Based on 30 companies-years observations of ROA, our analysis provide evidence that board size, board meeting and director's higher educational qualification are the characteristics that significantly influenced firm's performance. However, in oppose to the expectations of the study, inconclusive results are found concerning board independence and gender.

Our study provides several implications for policy and literature. First, the findings could be beneficial to the management, policymakers and regulators in the area of corporate governance. In other words, the regulators should strengthen the Board of directors' credentials, particularly in terms of ensuring they have good qualification background, as opposed to merely being a director in order to enable then to contribute effectively safeguarding the interest and maintain sustainability of the firm. Besides, our analysis shows that the firms should reduce the number of board members and the frequent board meeting which have negative relationship with firms' return on assets. Third, this study contributes to the extant literature on corporate governances, particularly on the characteristic of board members that influence their firms' performance.

However, this study has some limitations which should be addressed in future research. The first limitation is a small data sample as it only covers the nine years between 2011 and 2019. Hence, increasing the time duration under study for more years can be a prospective continuation in this regard to produce more substantial results. This study is having good prospects for future research by extended to the whole company listed on Bursa Malaysia rather than only selected one. In addition, the findings relied on quantitative analysis (regressions) which is insufficient. Therefore, more qualitative analysis is required (interviews with key decision-makers) to understand the position of board characteristic relationship 
INTERNATIONAL JOURNAL OF ACADEMIC RESEARCH IN ACCOUNTING, FINANCE AND

MANAGEMENT SCIENCES

Vol. 11, No. 1, 2021, E-ISSN: 2225-8329 ๔ 2021 HRMARS

\section{References}

Abdullah, S. N., \& Nasir, N. M. (2004). Accrual Management and The Independence Ofthe Boards Of Directors And Audit Committees. IIUM Journal of Economics and Management, 12(1), 49-80.

Adika, R. M., Maru, L., \& Mugambi, G. K. (2018). Effect Of Board Composition On Performance Of Firms Listed In The Nairobi Securities. The Strategic Journal of Business \& Change Management, 5(2), 1072 - 1087.

Al-Matari, E. M. A. (2011). Board Characteristics and Firm Performance Among Kuwaiti Companies. Doctoral dissertation, Universiti Utara Malaysia.

Al-Matari, Y. A., Al-Swidi, A. K., Fadzil, F., \& Al-Matari, E. M. (2012). Board of Directors, Audit Committee Characteristics and the Performance of Saudi Arabia Listed Companies. International Review of Management and Marketing, 2(4), 241-251.

Alomari, A. (2016). The Impact of Board of Directors and CEO Educational Qualifications and Experience on Performance: A Field Study on Manufacturing Companies Listed on the Amman Stock Exchange. Doctoral dissertation, Yarmouk University.

Arora, A., \& Sharma, C. (2016). Corporate Governance and Firm Performance in Developing Countries: Evidence from India. Corporate Governance International Journal of Business in Society, 16(2), 420-436.

Aryani, Y. A., Setiawan, D., \& Rahmawati, I. P. (2017). Board meeting and firm performance. Proceedings of International Conference on Economics 2017 (ICE 2017), (pp. 438 - 444).

Asteriou, D., \& Hall, S. G. (2015). Applied Econometrics. London: Red Globe Press.

Azar, A., Rad, F., \& Botyari, E. (2014). Board Characteristics And Firm Performance: Malaysian Evidence. Journal of Research in Business and Management, 2(6), 28-34.

Babu, N. S., \& Chalam, P. G. V. (2014). Key Factors Influencing Capital Structure Decision of Indian Computer Software Industry. INDIAN JOURNAL OF APPLIED RESEARCH, 4(6), 103-105.

Badu, L., \& Appiah, K. (2017). The Impact of Corporate Board Size on Firm Performance: Evidence from Ghana and Nigeria. Research in Business and Management, 4(2), 1-12.

Balagobei, S. (2018). Corporate Governance and Firm Performance: Empirical Evidence from Emerging Market. Asian Economic and Financial Review, 8(12), 1415-1421.

Bathula, H. (2008). Board Characteristics and Firm Performance: Evidence from New Zealand. Unpublished thesis submitted to Auckland University of Technology.

Bennouri, M., Chtioui, T., Nagati, H., \& Nekhili, M. (2018). Female board directorship and firm performance: What really matters? Journal of Banking \& Finance, 88, 267-291.

Bhagat, S., \& Black, B. (2002). The Non-Correlation Between Board Independence and Long-Term Firm performance. Journal of Corporate Law, 27(2), 231-274.

Biase, P., \& D'Apolito, E. (2012). The Determinants of Systematic Risk in the Italian Banking System: A Cross-Sectional Time Series Analysis. International Journal of Economics and Finance, 4(11), 152-164.

Binh, D., \& Anh, T. (2017). Stakeholders Approach On Corporate Governance and Performance Of Vietnamese Manufacturing Firms. Journal of Governance and Regulation, 6(2), 61-73.

Bonn, I., Yoshikawa, T., \& Phan, P. (2004). Effects of board structure on firm performance: A comparison between Japan and Australia. Asian Business \& Management, 3(1), 105-125.

Boubaker, S., Dang, R., \& Nguyen, D. K. (2014). Does board gender diversity improve the performance of French listed firms? Gestion 2000, 31(1), 259-269.

Bublykova, P. (2014). The Impact of Board Size on Firm Performance: Evidence from Hungary. 
INTERNATIONAL JOURNAL OF ACADEMIC RESEARCH IN ACCOUNTING, FINANCE AND

MANAGEMENT SCIENCES

Vol. 11, No. 1, 2021, E-ISSN: 2225-8329 @ 2021 HRMARS

Doctoral dissertation, Central European University.

Buchdadi, A., Ulupui, I., Dalimunthe, S., Pamungkas, B., \& Fauziyyah, Y. (2019). Board of Director Meeting and Firm Performance. Academy of Accounting and Financial Studies Journal, 23(2), 17.

Burke, R. (2003). Women On Corporate Boards Of Directors: The Timing is Right. Women in Management Review, 18(7), 346-348.

Carpenter, M., \& Westphal, J. (2001). The strategic context of external network ties: Examining the impact of director appointments on board involvement in strategic decision making. Academy of Management journal, Academy of Management journal, 639-660.

Carter, D., Simkins, B., \& Simpson, W. (2003). Corporate Governance, Board Diversity, and Firm Value. Financial Review, 38(1), 33-53.

Cho, S., Chung, C., \& Young, J. (2019). Study on the Relationship between CSR and Financial Performance. Sustainability, 11(2), 343.

Chow, Y. P., Muhammad, J., Bany-Ariffin, A. N., \& Cheng, F. F. (2018). Macroeconomic Uncertainty, Corporate Governance and Corporate Capital Structure. International Journal of Managerial Finance. https://doi.org/10.1108/IJMF-08-2017-0156

Christopher \& Lee Ong: Malaysia. (2017). Corporate: The Malaysian Code on Corporate 2017, pp. 16. Retrieved from Rajah \& Tann Asia: Lawyer Who Know Asia: https://www.christopherleeong.com/

Clarke, T. (2007). International Corporate Governance: A Comparative Approach. Routledge.

Coles, J., Daniel, N., \& Naveen, L. (2008). Boards: Does one size fit all? Journal of financial economics, 87(2), 329-356.

Core, J. E., Holthausen, R. W., \& Larcker, D. F. (1999). Corporate governance, chief executive officer compensation, and firm performance. Journal of Financial Economics, 51(3), 371-406.

Dagsson, S., \& Larsson, E. (2011). How age diversity on the Board of Directors affects Firm Performance. Unpublished master's thesis, Blekinge Institute of Technology School of Management .

Daily, C., Dalton, D., \& Cannella Jr, A. (2003). Corporate governance: Decades of dialogue and data. Academy of management review, 28(3), 371-382.

Dalton, D., Daily, C., Ellstrand, A., \& Johnson, J. (1998). Meta-analytic reviews of board composition, leadership structure, and financial performance. Strategic management journal, 19(3), 269-290.

Davis, J., Schoorman, F., \& Donaldson, L. (1997). Toward a Stewardship Theory of Management. The Academy of Management Review, 22(1), 20-47.

Denis, D. K., \& McConnell, J. J. (2003). International Corporate Governance. The Journal of Financial and Quantitative Analysis, 38(1), 1-36.

Doğan, M., \& Yildiz, F. (2013). The Impact Of The Board Of Directors' Size On The Bank's Performance: Evidence From Turkey. European Journal of Business and Management, 5(6), 130-140.

Donaldson, L., \& Davis, J. (1991). Stewardship theory or agency theory: CEO governance and shareholder returns. Australian Journal of management, 16(1), 49-64.

Dunn, P., \& Sainty, B. (2009). The relationship among board of director characteristics, corporate social performance and corporate financial performance. International Journal of Managerial Finance, 5(4), 407-423.

Eisenhardt, K. (1989). Agency theory: An assessment and review. Academy of Management Review, 14(1), 57-74. 
INTERNATIONAL JOURNAL OF ACADEMIC RESEARCH IN ACCOUNTING, FINANCE AND

MANAGEMENT SCIENCES

Vol. 11, No. 1, 2021, E-ISSN: 2225-8329 @ 2021 HRMARS

Eluyela, D., Akintimehin, O., Okere, W., Emmanuel, O., Osuma, G. O., Ilogho, S. O., \& Oladipoa, O. A. (2018). Board meeting frequency and firm performance: examining the nexus in Nigerian deposit money bank. Heliyon, 4(10), 850.

Endraswati, H. (2018). Gender Diversity in Board of Directors and Firm Performance: A Study in Indonesia Sharia Banks. Review of Integrative Business and Economics Research, 7(1), 299-311.

Ezzamel, M., \& Watson, R. (2005). Boards of directors and the role of non-executive Directors in the governance of corporation. In K. Keasey, S. Thompson, \& M. Wright, Corporate governance: Accountability, Enterprise and International Comparisons (pp. 97 - 115). West Sussex, England: John Wiley and Sons Ltd.

Ezzamel, M., \& Watson, R. (1993). Organizational Form, Ownership Structure and Corporate Performance: A Contextual Empirical Analysis of UK Companies. British Journal of Management, 4(3), 161-176.

Fauzi, F., \& Locke, S. (2012). Board Structure, Ownership Structure And Firm Performance: A Study Of New Zealand Listed-firms. sian Academy of Management Journal of Accounting of Finance, 8(2), 43-67.

Freeman, R. (1983). Stockholders and Stakeholders: A New Perspective on Corporate Governance. California Management Review, 25(3).

Frijling, L., Wang, R., \& Lemmen, J. (2016). Board composition and firm performance: gender diversity, board independence. Master thesis, Erasmus University Rotterdam.

Fuzi, S. S., Halim, S. A., \& Khudzari, J. (2016). Board Independence and Firm Performance. Procedia Economics and Finance, 37, 460-465.

Gambo, E., Bello, B., \& Rimamshung, S. (2018). Effect of board size, board composition and board meetings on financial performance of listed consumer goods in Nigeria. International Business Research, 11(6), 1-10.

Gani, L., \& Jermias, J. (2006). Investigating the effect of board independence on performance across different strategies. The International Journal of Accounting, 41(3), 295-314.

Ghabayen, M. (2012). Board Characteristics and Firm Performance: Case of Saudi Arabia. International Journal of Accounting and Financial Reporting, 2(2), 168-200.

Ghosh, S. (2007). Board Diligence, Director Business And Corporate Governance. Corporate Board: Role, Duties \& Composition, 3(3), 91-104.

Gurusamy, P. (2017). Board Characteristics, Audit Committee and Ownership Structure Influence on Firm Performance of Manufacturing Firms in India. International Journal of Business and Economics Research, 6(4), 73-87. https://doi.org/10.11648/j.ijber.20170604.16

Haat, M. C., Rahman , R., Hamid, N., \& Mahenthiran , S. (2006). The Factors That Cause Companies To Be Suspended From The Kuala Lumpur Stock Exchange. Malaysian Accounting Review, 5(1), 115-138.

Hämäläinen, H. (2016). Market Reaction Towards Ceo Appointments: Do Executive Gender And Age Matter? Unpublished master's thesis Programme in Finance, University Of Vaasa.

Hambrick, D., \& Mason , P. (1984). Upper echelons: The organization as a reflection of its top managers. Academy of management review, 9(2), 193-206.

Harrison, J., \& Wicks, A. (2013). Stakeholder Theory, Value, and Firm Performance. Business Ethics Quarterly, 23(1), 97-125.

Hassan, N. N. N. M., Shafi, R. M., \& Mohamed, S. (2012). The Determinants of Capital Structure: Evaluation between Shariah-Compliant and Conventional Companies. International Conference 
INTERNATIONAL JOURNAL OF ACADEMIC RESEARCH IN ACCOUNTING, FINANCE AND

MANAGEMENT SCIENCES

Vol. 11, No. 1, 2021, E-ISSN: 2225-8329 @ 2021 HRMARS

on Innovation, Management and Technology Research, 205-209.

https://doi.org/10.1109/ICIMTR.2012.6236389

Heng, T. B., Azrbaijani, S., \& San, O. T. (2012). Board of Directors and Capital Structure: Evidence from Leading Malaysian Companies. Asian Social Science, 8(3), 123-136.

https://doi.org/10.5539/ass.v8n3p123

Hermalin, B., \& Weisbach, M. (2002). The effect of board compositions and direct incentive on firm performance. Financial Management, 20(4), 101-112.

Hillman, A., Canella, A., \& Paetzold, R. (2000). The resource dependency role of corporate governance directors: Strategic adaptation of board composition in response to environmental change. Journal of Management Studies, 37(2), 2322-2380.

Hilmer, F. (1998). Strictly Boardroom (2nd edition). Melbourne: Information Australia.

Hitt, M., Ireland, R., \& Hoskisson, R. (2009). Strategic Management: Competitiveness and Globalization (8th ed.). USA: South-Western Cengage Learning.

Huse, M., \& Solberg, A. (2006). Gender related boardroom dynamics: How women make and can make contributions on corporate boards. Women in Management Review, 21(2), 113-130.

Ilaboya, O., \& Obaretin, O. (2015). Board Characteristics and Firm Performance: Evidence from Nigerian Quoted Companies. Academic Journal of Interdisciplinary Studies, 4(1), 283-290.

Ionascu, M., Ionascu, I., Sacarin, M., \& Minu, M. (2018). Women on boards and financial performance: Evidence from a European emerging market. Sustainability, 10(5), 1644.

Isik, O., \& Ince, A. (2016). Board size, board composition and performance: An investigation on Turkish banks. International Business Research, 9(2), 74-84.

Jakpar, S., Tinggi, M., hui, T. K., Johari, A., \& Myint, K. T. (2019). Analysis of Corporate Governance and Firm Performance: Evidence from Malaysian Listed Companies. International Journal of Business and Social Science, 10(1), 2219-6021.

Jensen, I., \& Meckling, W. (1976). Theory of the firm: Managerial behavior, agency costs and ownership structure. Journal of Financial Economics, 3(4), 305-360. 